Abstract 102 Table 1 Comparison of enzyme activity of Catalase, Superoxide Dismutase and Glutathione Peroxide in kidney, Liver, lung and spleen at 0 month, after 6 month pristane treatment and after resveratrol treatment. Values are expressed as Mean \pm SEM. Catalase Units: $\mu M$ of $\mathrm{H}_{2} \mathrm{O}_{2}$ decomposed per minute. Superoxide Dismutaes Units: Amount of enzyme which inhibits the rate of reaction by $50 \%$ per minute. Glutathoine Peroxidase: $\mu \mathrm{M}$ of NADPH oxidised per minute.

\begin{tabular}{|c|c|c|c|c|c|}
\hline & & Kidney & Liver & Lung & Spleen \\
\hline \multirow{3}{*}{$\begin{array}{l}\text { Catalase } \\
\text { (Unitsimg } \\
\text { protein) }\end{array}$} & Omonth & $38.61 \pm 4.22$ & $49.36 \pm 2.26$ & $29.38 \pm 3.44$ & $8.2 \pm 0.97$ \\
\hline & $\begin{array}{l}6 \text { month } \\
\text { pristane }\end{array}$ & $31.97 \pm 2.3$ & $47.71 \pm 1.24$ & $14.31 \pm 1.67$ & $6.66 \pm 0.29$ \\
\hline & Resveratrol & $29.56 \pm 3.25$ & $40.63 \pm 3.2$ & $18.81 \pm 3.34$ & $7.06 \pm 0.8$ \\
\hline \multirow{3}{*}{$\begin{array}{l}\text { Superoxide } \\
\text { Dismutase } \\
\text { (Unitsing } \\
\text { protein) }\end{array}$} & Omonth & $19.27 \pm 1.64$ & $15.17 \pm 0.8$ & $34.67 \pm 4.07$ & $21.96 \pm 0.74$ \\
\hline & $\begin{array}{l}6 \text { month } \\
\text { pristane }\end{array}$ & $14.24 \pm 0.97$ & $12.32 \pm 0.7$ & $19.68 \pm 1.04$ & $10.33 \pm 1.81$ \\
\hline & Resveratrol & $16.61 \pm 1.48$ & $12.98 \pm 0.19$ & $25.71 \pm 5.1$ & $13.16 \pm 1.19$ \\
\hline \multirow{3}{*}{$\begin{array}{l}\text { Glutathione } \\
\text { Peroxidase } \\
\text { (Unitsing } \\
\text { protein) }\end{array}$} & Omonth & $35.30 \pm 3.29$ & $28.65 \pm 2.24$ & $24.85 \pm 3.95$ & $31.34 \pm 2.62$ \\
\hline & $\begin{array}{l}6 \text { month } \\
\text { pristane }\end{array}$ & $19.7 \pm 3.52$ & $15.84 \pm 2.11$ & $13.56 \pm 2.67$ & $23.99 \pm 2.19$ \\
\hline & Resveratrol & $24.36 \pm 3.75$ & $15.30 \pm 3.36$ & $13.52 \pm 1.86$ & $23.03 \pm 5.9$ \\
\hline
\end{tabular}

after 6 months. $25 \mathrm{mg} / \mathrm{kg}$ body weight of resveratrol was given orally after 2 months of pristane administration daily for the next 4 months.

Results The increased level of reactive oxygen species (Mean Flourescence value at 0 month: $1.70 \pm 0.22$ to $4.89 \pm 1.37$ at 6 months) in peripheral blood mononuclear cells in the model decreased significantly after resveratrol treatment $(1.75 \pm 0.21)$. Pristane treatment decreased the activity of antioxidant enzymes like Catalase in lungs, Superoxide Dismutase in lungs and spleen and Glutathione peroxidase in liver and lungs. Resveratrol increased the activity of all these enzymes and a significant increase was observed in the activity of Superoxide Dismutase in lungs. Pristane treatment decreased the levels of reduced glutathione and increased lipid peroxidation in kidneys, liver, lungs and spleen. Resveratrol treatment restored reduced glutathione level and decreased lipid peroxidation.

Conclusions In conclusion this study states that, the consumption of resveratrol helps in better management of the disease by combating oxidative stress, the root cause of different manifestations observed in lupus.

\section{SMOKING AND PRE-EXISTING ORGAN DAMAGE REDUCE THE EFFICACY OF BELIMUMAB IN SYSTEMIC LUPUS ERYTHEMATOSUS}

${ }^{1}$ I Parodis*, ${ }^{2} \mathrm{C}$ Sjöwall, ${ }^{3} \mathrm{~A}$ Jönsen, ${ }^{1} \mathrm{D}$ Ramsköld, ${ }^{1} \mathrm{~A}$ Zickert, ${ }^{2} \mathrm{M}$ Frodlund, ${ }^{4} \mathrm{~A}$ Sohrabian, ${ }^{5} \mathrm{~L}$ Arnaud, ${ }^{4} \mathrm{~J}$ Rönnelid, ${ }^{1} \mathrm{~V}$ Malmström, ${ }^{3} \mathrm{AA}$ Bengtsson, II Gunnarsson. ' Karolinska Institutet, Department of Medicine- Rheumatology Unit, Stockholm, Sweden; ' Linköping University, Department of Clinical and Experimental Medicine- Rheumatology/AIR, Linköping, Sweden; ${ }^{3}$ Lund University, Department of Clinical Sciences Lund- Rheumatology, Lund, Sweden; ${ }^{4}$ Uppsala University, Department of Immunology- Genetics and Pathology, Uppsala, Sweden; ${ }^{5}$ Hôpitaux Universitaires de Strasbourg, Service de Rhumatologie- Centre National de Référence pour les Maladies Auto-Immunes Systémiques Rares, Strasbourg, France

\subsection{6/lupus-2017-000215.103}

Background and aims Belimumab is the first biologic drug approved for Systemic Lupus Erythematosus (SLE). Here, we aimed to investigate the effects of belimumab on clinical and serologic outcomes, and sought to identify predictors of treatment response in three Swedish real-life settings. 
Abstract 102 Table 2 Comparision of the levels of reduced glutathione and lipid peroxidation in Kidney, liver, lung and spleen at 0 month, 6 month pristane treatment and after resveratrol treatment. Values are expressed as Mean \pm SEM.

\begin{tabular}{|c|c|c|c|c|c|}
\hline & & Kidney & Liver & Lung & Spleen \\
\hline \multirow{3}{*}{$\begin{array}{l}\text { Reduced } \\
\text { Glutathione } \\
\text { (umolesing } \\
\text { protein) }\end{array}$} & 0 month & $4.53 \pm 0.37$ & $5.71 \pm 0.46$ & $9.67 \pm 1.35$ & $8.83 \pm 2.10$ \\
\hline & 6 month & $2.23 \pm 0.37$ & $2.03 \pm 0.86$ & $3.21 \pm 0.99$ & $4.91 \pm 0.91$ \\
\hline & Resveratrol & $5.13 \pm 0.57$ & $5.45 \pm 0.21$ & $5.59 \pm 0.1$ & $9.88 \pm 0.46$ \\
\hline \multirow{3}{*}{$\begin{array}{l}\text { Lipid Peroxidation } \\
\text { (umoles MDAmg } \\
\text { protein) }\end{array}$} & 0 month & $1.35 \pm 0.17$ & $2.34 \pm 0.5$ & $1.58 \pm 0.52$ & $1.58 \pm 0.27$ \\
\hline & 6 month & $7.56 \pm 0.78$ & $10.62 \pm 1.08$ & $5.01 \pm 0.53$ & $6.27 \pm 0.48$ \\
\hline & Resveratrol & $2.78 \pm 0.16$ & $4.22 \pm 0.53$ & $4.29 \pm 0.84$ & $3.74 \pm 0.69$ \\
\hline
\end{tabular}

Methods Fifty-eight patients were enrolled at initiation of belimumab and followed longitudinally for up to 53 months. Surveillance outcomes included the SLE Disease Activity Index 2000 (SLEDAI-2K), $100 \mathrm{~mm}$ Visual Analogue Scales for Physician's Global Assessment (PGA), fatigue, pain and general health, and the Systemic Lupus International Collaborating Clinics/American College of Rheumatology Damage Index (SDI). Assessment of treatment response included the SLE responder index (SRI). B lymphocyte stimulator (BLyS) levels were determined using ELISA.

Results SLEDAI-2K (median baseline score: 8.0; IQR: 4.013.8), PGA and corticosteroid use decreased during therapy, and patients reported improvements on fatigue, pain, and general health $(p<0.0001$ for all). SDI scores remained stable $(p=0.08)$. Patients with baseline SDI scores $>1$ showed decreased probability and prolonged time to attain SRI response (HR: 0.449; 95\% CI: 0.208-0.967), as did current smokers compared with non-smokers (HR: 0.103; 95\% CI: $0.025-0.427)$. In contrast, baseline BLyS levels $\geq 1.2 \mathrm{ng} / \mathrm{mL}$ predicted increased probability and shorter time to attain SRI response (HR: 2.566; 95\% CI: 1.222-5.387).

Conclusions Disease activity and corticosteroid usage decreased, patient-reported outcomes improved, and no significant organ damage was accrued during follow-up. Smoking and organ damage predicted reduced treatment efficacy. These findings might contribute to a better selection of patients who are likely to benefit from belimumab.

\section{A MASS CYTOMETRY (CYTOF) APPROACH TO STUDY B CELL ALTERATIONS DURING BAFF BLOCKADE TREATMENT WITH BELIMUMAB IN SYSTEMIC LUPUS ERYTHEMATOSUS}

'I Parodis*, 'D Ramsköld, ${ }^{2} \mathrm{~L}$ Tadepally, ${ }^{2} Y$ Chen, ${ }^{1} \mathrm{~A}$ Zickert, ${ }^{2} \mathrm{~J}$ Mikes, ${ }^{1} \mathrm{~K}$ Amara, ${ }^{2} \mathrm{~A}$ Achour, ${ }^{2} \mathrm{P}$ Brodin, ${ }^{1}$ I Gunnarsson, ${ }^{1} \mathrm{~V}$ Malmström. ${ }^{1}$ Karolinska Institutet, Department of Medicine- Rheumatology Unit, Stockholm, Sweden; ${ }^{2}$ Karolinska Institutet, Department of Medicine Solna- Science for Life Laboratory, Stockholm, Sweden

\subsection{6/lupus-2017-000215.104}

Background and aims Belimumab is a monoclonal antibody that inhibits soluble B lymphocyte stimulator (BLyS, also known as BAFF), approved for the treatment of systemic lupus erythematosus (SLE). Here, we sought to identify B cell alterations during belimumab treatment.

Methods Twenty-three SLE patients treated with belimumab were enrolled. Peripheral blood mononuclear cells were collected and cryopreserved at treatment initiation and at regular follow-up visits for up to 3 years. The samples were simultaneously assayed using mass cytometry. Cell counts were adjusted for total lymphocyte counts.

Results CD20 ${ }^{+}$B cells decreased over time $(\mathrm{p}<0.0001)$. We observed a rapid reduction of naïve $\left(\mathrm{CD} 19^{+} \mathrm{CD} 20^{+} \mathrm{Ig}\right.$ $\left.\mathrm{D}^{+} \mathrm{IgM}^{+} \mathrm{CD} 27^{-}\right)$and age-associated $\mathrm{B}$ cells $\left(\mathrm{CD} 19^{+} \mathrm{CD} 20^{+} \mathrm{CD} 11 \mathrm{c}^{+} \mathrm{CD} 21^{-}\right)$already at the first follow-up visit (month 3 ), followed by a continuous decrease $(\mathrm{p}<0.0001$ for both subsets), while double-negative memory B cells 